JPdK Volume 3 Nomor 2 Tahun 2021 Halaman 72-75

JURNAL PENDIDIKAN dan KONSELING

Research \& Learning in Primary Education

\title{
Analisis Pemahaman Siswa Terhadap Materi Bangun Ruang Sisi Datar Pada Masa Pandemi
}

\author{
Widya Norma Ambardi ${ }^{1}$, Elma Velia Yuniarti ${ }^{2}$, Viona Adinda Rosalina ${ }^{3}$, Arin Safitri ${ }^{4}$, Juniar Retno \\ Anggaraini $^{5}$, Darmadi ${ }^{6}$
}

Program Studi Pendidikan Matematika,

Fakultas Keguruan dan Ilmu Pendidikan,

Universitas PGRI Madiun

Email : normawidya619@ gmail.com, elmavelia541@ gmail.com, vionaadinda4321@ gmail.com, arinsafitrii25@gmail.com, juniarretno3@gmail.com, darmadixmadiun@gmail.com

\begin{abstract}
Abstrak
Selama pandemi seperti ini siswa melakukan pembelajaran secara online. Pada penelitian ini bertujuan untuk menganalisis pemahaman siswa terhadap materi bangun ruang sisi datar pada masa pandemi. Penelitian ini dilakukan kepada siswa SMP kelas VIII dan instrument yang digunakan pada penelitian ini yaitu berupa angket. Kesimpulan pada penelitian ini adalah mengenai analisis pemahaman siswa terhadap materi bangun ruang sisi datar pada masa pandemi yang diberikan kepada dua puluh enam siswa kelas VIII terbagi menjadi empat kategori yaitu pemahaman sangat tinggi, pemahaman tinggi, pemahaman cukup dan pemahaman rendah. Mayoritas siswa yang mengisi angket tersebut memiliki pemahaman yang tinggi.
\end{abstract}

Kata kunci : Pemahaman, Bangun Ruang Sisi Datar, Pandemi.

\begin{abstract}
During a pandemic like this, students study online. In this study, the aim of this study was to analyze students' understanding of the material on the flat side of the space during the pandemic. This research was conducted on VIII grade junior high school students and the instrument used in this study was a questionnaire. The conclusion in this study is about the analysis of students' understanding of the flat-sided space construction material during the pandemic which was given to twenty-six VIII grade students divided into four categories, namely very high understanding, high understanding, sufficient understanding and low understanding. The majority of students who filled out the questionnaire had a high understanding.
\end{abstract}

Keywords : Understanding, Geometry Flat Side, Pandemic.

\section{PENDAHULUAN}

Pada tahun 2019 terjadi penemuan baru berupa virus yang menguncangkan berbagai negara di dunia. Virus tersebut bernama coronavirus disiase yang biasa dikenal dengan (covid 19) yang berasal dari Wuhan,China . Jumlah pengidap yang dinyatakan positif terpapar virus sangat signifikan sehingga protokol kesehatan diperketat dan berlakunya isolasi . Karantina selama 14 hari juga dilakukan upaya memutus mata rantai penyebaran virus. Semua aktivitas terkendala baik segi ekonomi,pendidikan ,pembangunan dan lain - lain. Beberapa negara memiliki kebijakan yang wajib diikuti semua warga agar membatasi interaksi dengan orang lain.
Bidang pendidikan misalnya sekolah yang diliburkan, sehingga peserta didik bertransformasi melakukan pembelajaran secara daring yang tak terbatas oleh jarak dan waktu dan tidak dapat bertatap muka. Internet penunjang dalam pembelajaran daring, sinyal yang stabil dibutuhkan agar pembelajaran dapat disampaikan dengan baik dan benar. Beberapa ciri - ciri yang harus diperhatikan dalam pembelajaran daring contohnya spirit belajar,literasi belajar,kemampuan berkomunikasi, kolaborasi dan terampil mandiri (Hasanah, Ambar, Alvin, \& Yudi, 2020). Pemahaman dapat dicapai jika materi yang dibentuk sedemikian rupa agar lebih mudah dipahami dan model pembelajaran yang bervariasi dapat diterapkan supaya tidak membosankan. Dengan demikian seiring berjalannya waktu guru lebih kreatif dan inovatif dalammenyusun materi. Beberapa platform tambahan seperti Whats 
App,Google Meet,Zoom,Google Classroom dan sebagainya diharapkan dapat mendukung dicapainya kompetensi dan bidang matematika secara logis,kritis,analisis dan lain - lain (Setyowati \& Muwardi, 2018).Tujuan diadakannya penelitian ini dapat mengetahui tentang pemahaman siswa dalam menyelesaikan soal maupun kontekstual yang berkaitan dengan bangun ruang sisi datar secara daring,sehingga dapat menyelesaikan dengan baik.

\section{METODOLOGI PENELITIAN}

Subjek penelitian ini adalah dua puluh enam siswa kelas VIII Sekolah Menengah Pertama. Penelitian dilaksanakan pada tanggal 17 Juni 2021 menggunakan metode daring. Metode yang digunakan pada penelitian ini adalah metode penelitian kuantitatif dengan pendekatan deskriptif. Menurut Sugiyono (2013: 13), metode penelitian kuantitatif dapat diartikan sebagai metode penelitian yang berdasarkan pada filsafat positivisme, digunakan untuk meneliti pada populasi atau sampel tertentu, teknik pengambilan sampel pada umumnya dilakukan secara random, pengumpulan data menggunakan instrument penelitian, analisis data bersifat kuantitatif atau stastistik dengan tujuan untuk menguji hipotesis yang telah ditetapkan. Penelitian ini menggunakan pendekatan deskriptif dengan tujuan untuk mendeskripsikan objek penelitian atau hasil penelitian. Menurut Sugiyono (2012: 29) deskriptif adalah metode yang berfungsi untuk mendeskripsikan atau memberi gambaran terhadap objek yang diteliti melalui data atau sampel yang telah terkumpul sebagaimana adanya tanpa melakukan analisis dan membuat kesimpulan yang berlaku umum.

Teknik pengambilan sampel yang dilakukan menggunakan teknik probability sampling yaitu teknik pengambilan data yang tidak berdasarkan pemilihan dengan kriteria atau ciri-ciri khusus untuk mendapatkan hasil relevan dari suatu tujuan penelitian, maka teknik ini bisa dikatakan dengan random sampling atau mengambil sampel secara acak. Pada penelitian ini menggunakan probability sampling karena mengingat sekarang ini masih terjadi pandemi covid-19 dan situasi serta kondisi yang tidak memungkinkan untuk bertemu langsung dengan siswa. Pengumpulan data pada penelitian ini menggunakan wawancara dan angket mengenai materi bangun ruang sisi datar pada siswa kelas VIII Sekolah Menengah Pertama. Angket merupakan teknik pengumpulan data yang dilakukan dengan cara memberikan seperangkat pertanyaan atau pernyataan tertulis kepada responden untuk dijawabnya. Sehingga dengan wawancara dan angket ini dapat digunakan untuk mengetahui sejauh mana pemahaman siswa mengenai materi bangun ruang sisi datar pada kelas VIII Sekolah Menengah Pertama.

Pada penelitian ini mengambil data menggunakan wawancara yang dilakukan melalui google formulir. Berikut beberapa pertanyaan yang digunakan dalam wawancara:

1. Apakah anda memperhatikan ketika guru mengajar secara daring?

2. Selain membaca buku matematika, apakah anda mencari sumber lain yang mendung materi yang dipelajari?

3. Bagaimana cara anda berdiskusi dengan teman mengenai masalah atau tugas yang diberikan guru?

4. Apakah anda mendengarkan secara seksama penjelasan guru yang disampaikan secara daring?

5. Bagaimana cara anda mengerjakan tugas? Apakah langsung dikerjakan atau menunda?

6. Bagaimana sikap anda saat kelompok lain sedang presentasi?

7. Apakah anda takut dalam menyampaikan pendapat kepadaguru?

8. Apabila anda mengalami kesulitan bagaimana sikap anda?

9. Bagaimana sikap anda saat guru menerangkan pelajaran tetapi teman anda mengajak berbicara?

10. Apakah anda bermain sendiri ketika guru menyampaikan pelajaran?

Selain mengambil data dari melakukan wawancara pada penelitian ini juga menggunakan angket yang dilakukan juga melalui google formulir dan pelaksanaannya bersamaan dengan wawancara. Angket analisis pemahaman sisiwa mengenai bangun ruang sisi datar menggunakan Instrument Skala Likert, Menurut Sugiyono (2015) skala likert akan berguna bila peneliti ingin melakukan pengukuran secara keseluruhan suatu topik. Instrument skala likert mempunyai jawaban yang gradasi dari sangat negatif sampai sangat positif. Pernyataan dalam angket analisis pemahaman siswa mengenai bangun ruang sisi datar sebagai berikut:

Tabel 1. Pernyataan angket analisis pemahaman siswa mengenai bangun ruang sisi datar

\begin{tabular}{|c|c|c|c|c|c|}
\hline \multirow{2}{*}{ No } & \multirow{2}{*}{ Pernyataan } & \multicolumn{4}{|c|}{ Alternatif Jawaban } \\
\hline & & SS & $\mathbf{S}$ & $\mathbf{M}$ & $\mathbf{S M}$ \\
\hline 1 & 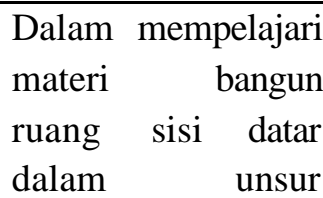 & & & & \\
\hline
\end{tabular}




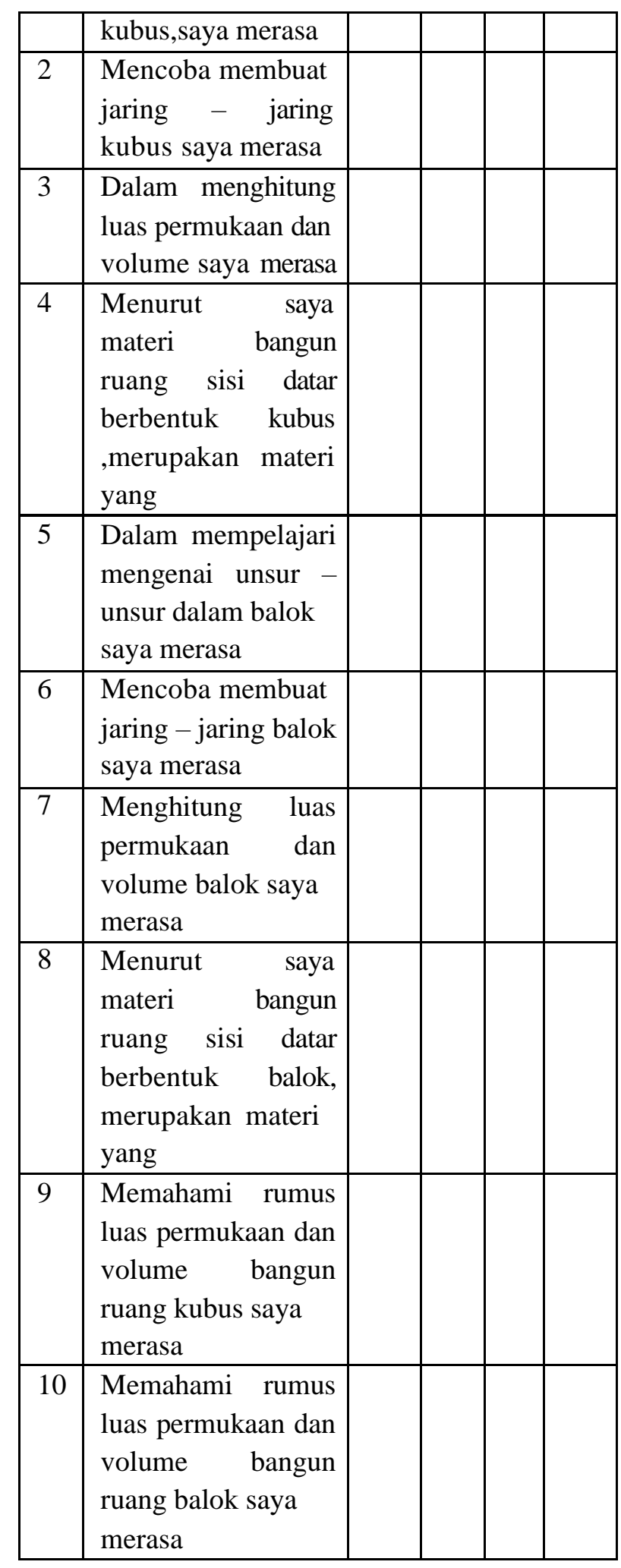

Keterangan:

SS : Sangat Sulit

S : Sulit

M : Mudah

SM : Sangat Mudah

Cara menentukan nilai pada angket analisis pemahaman siswa mengenai bangun ruang sisi datar pada Tabel 1, berikut (Fauzan and Aripin, 2019)

Tabel 2. Penentuan nilai angket

\begin{tabular}{|c|c|c|c|}
\hline $\begin{array}{c}\text { Pernyataan } \\
\text { Positif }\end{array}$ & Poin & $\begin{array}{c}\text { Pernyataan } \\
\text { Negatif }\end{array}$ & Poin \\
\hline SS & 4 & SS & 1 \\
\hline S & 3 & S & 2 \\
\hline
\end{tabular}

\begin{tabular}{|c|c|c|c|}
\hline M & 2 & M & 3 \\
\hline SM & 1 & SM & 4 \\
\hline
\end{tabular}

Menurut (Jatmiko, 2015) klasifikasi dapat dihitung dengan langkah-langkah yaitu menentukan rerata (x), seluruh skor angket siswa, menentukan simpangan baku $(\delta)$ seluruh skor angket siswa, dan menentukan klasifikasi. Tabel 3 merupakan pedoman pengklasifikasikan analisis pemahaman siswa mengenai bangun ruang sisi datar.

Tabel 3. Pedoman pengklasifikasikan analisis pemahaman siswa mengenai bangun ruang sisi datar

\begin{tabular}{|c|c|}
\hline Klasifikasi & Skor \\
\hline Pemahaman sangat tinggi & $\mathrm{x}+3 \delta \leq$ skor \\
\hline Pemahaman tinggi & $\mathrm{x}+\delta \leq$ skor $<\mathrm{x}+$ \\
& $3 \delta$ \\
\hline Pemahaman cukup & $\mathrm{x}-\delta \leq$ skor $<\mathrm{x}+\delta$ \\
\hline Pemahaman rendah & $\mathrm{x}-3 \delta \leq$ skor $<\mathrm{x}-\delta$ \\
\hline
\end{tabular}

\section{HASIL PENELITIAN DAN PEMBAHASAN}

Angket pemahaman siswa terhadap materi bangun ruang sisi datar pada masa pandemi telah diberikan kepada dua puluh enam siswa kelas VIII memiliki hasil perhitungan dan klasifikasi nilai angket yang disajikan dalam gambar diagram berikut

\section{Klasifikasi pemahaman siswa}

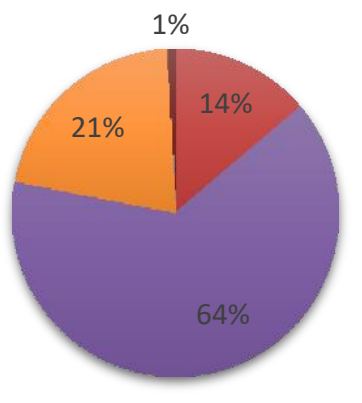

$$
\begin{aligned}
& \text { Pemahaman } \\
& \text { sangat tinggi } \\
& \text { Pemahaman } \\
& \text { tinggi } \\
& \text { pemahaman } \\
& \text { cukup } \\
& \text { pemahaman } \\
& \text { rendah }
\end{aligned}
$$

Berdasarkan gambar diagram tersebut diperoleh siswa dengan tingkat pemahaman yang sangat tinggi terhadap materi bangun ruang sisi datar yaitu $14 \%$ atau sebanyak 3 siswa, siswa dengan tingkat pemahaman yang tinggi terhadap materi bangun ruang sisi datar yaitu 64\% atau sebanyak 17 siswa, siswa dengan tingkat pemahaman yang cukup terhadap materi bangun ruang sisi datar yaitu $21 \%$ atau sebanyak 5 siswa, siswa dengan tingkat pemahaman yang rendah terhadap materi bangun ruang sisi datar yaitu $1 \%$ atau sebanyak 1 siswa.

Siswa dengan tingkat pemahaman yang tinggi menjadi jumlah terbanyak dibandingkan dengan kategori yang lain. Sedangkan tingkat pemahaman rendah menjadi jumlah yang paling sedikit yaitu hanya 1 siswa saja. Siswa dengan tingkat pemahaman yang sangat tinggi terhadap materi bangun ruang sisi datar mempunyai motivasi belajar yang tinggi pula, selama proses pembelajaran daring selalu 
memperhatikan guru, aktif bertanya dan berdiskusi, tidak mudah terpengaruh dengan siswa lain, dan mengikuti pembelajaran dengan sangat baik. Sesuai dengan hasil wawancara yang telah dilakukan, selama masa pandemi ini siswa yang memiliki tingkat pemahaman materi yang tinggi dapat menyesuaikan diri dengan baik, siswa dapat belajar dengan media atau sumber buku lainnya yang menunjang pemahaman meraka terhadap materi yang diberikan oleh guru.

Siswa dengan tingkat pemahaman yang rendah terhadap materi bangun ruang sisi datar mempunyai beberapa masalah pada motivasi belajarnya, selama pembelajaran mereka kurang memperhatikan guru karena asyik bermain sendiri, dan siswa sering menunda atau bahkan tidak mengerjakan tugas yang diberikan oleh guru. Ketika siswa tersebut tidak mengerti pada materi tersebut malu untuk bertanya dan diam saja, hal ini mengakibatkan tingkat pemahaman pada beberapa siswa rendah. Berdasarkan angket yang diberikan kepada dua puluh enam siswa, mereka merasa sulit pada materi jaring-jaring kubus dan balok, unsur-unsur balok, dan luas permukaan serta volume bangun ruang kubus.

\section{SIMPULAN}

Simpulan pada penelitian kami yang mengenai analisis pemahaman siswa terhadap materi bangun ruang sisi datar padamasa pandemi yang diberikan kepada dua puluh enam siswa kelas VIII terbagi menjadi empat kategori yaitu pemahaman sangat tinggi, pemahaman tinggi, pemahaman cukup dan pemahaman rendah. Siswa dengan tingkat pemahaman yang tinggi menjadi jumlah terbanyak dibandingkan kategori lain dan siswa dengan tingkat pemahaman rendah menjadi jumlah yang paling sedikit dibandingkan kategori lain. Sesuai dengan angket yang diberikan sebagian besar siswa merasa kesulitan pada materi jaring-jaring kubus dan balok, unsur-unsur balok, dan luas permukaan serta volume bangun ruang kubus.

\section{DAFTAR PUSTAKA}

Aan Hasanah, A. S. (2020). Analisis Aktivitas Belajar Daring Mahasiswa Pada Pandemi Covid-19. Google Scholar .

Aripin, G. A. (2019). Penerapan Ice Breaking dalam Pembelajaran Matematika untuk Meningkatkan Rasa Percaya Diri Siswa VIII B SMP Bina Harapan Bangsa. JPIM (Jurnal Pembelajaran Matematika Inovatif) , 17-24.
Dini Nuraeni, D. A. (2020). Analisis Pemhaman Kognitif Matematika Sudut Menggunakan Video Pembelajaran Matematika Sistem Daring di Kelas IV B SDN Pintukisi. Google Scholar .

Jatmiko. (2015). Hubungan Motivasi Belajar Matematika Siswa Kelas X SMK Nahdhatul Ulama Pace Nganjuk. Math Educator Nusantara , 205-213.

N Setyowati, M. M. (2018). Analisis Kemampuan Pemahaman Kognitif Dan Kesulitan Belajar . Google Scholar.

Sugiyono. (2012). Memahami Penelitian Kualitatif . Bandung: Alfabeta.

Sugiyono. (2013). Metode Penelitian Pendidikan Pendekatan Kuantitatif, Kualitatif, dan R\&D. Bandung: Alfabeta.

Sugiyono. (2015). Quantitative Research Methods. Bandung: Alfabeta. 